\title{
Extraction of Coconut Milk by Continuous Screw Press ${ }^{1}$
}

\author{
L. E. Cancel, J. A. Rosario-Hernández, and E. R. de Hernández ${ }^{2}$
}

\section{INTRODUCTION}

One of the most important operations in the extraction of coconut milk is the pressing of the comminuted pulp. A rack and cloth hydraulic press (3) is used presently for this. A roller mill press (5) and a combination of centrifuge and rack cloth press $(4,6)$ also have been used.

The rack and cloth hydraulic press system has been used extensively in industry in Puerto Rico for this purpose. The operation has been studied thoroughly and found to be efficient. It has the disadvantage of being a batch-type operation, however, requiring at least two operators to make it practical. The main objections to the batch process are the difficulties in standardizing it and its high operating costs. The rack and cloth hydraulic press system also presents sanitation and quality problems. As cloth is used to hold the comminuted pulp, the cleaning and maintenance of this material adds to the cost of production. The use of the required racks also creates a cleaning problem. Due to their construction design, this accessory has to be sanitized thoroughly or the flavor of the finished product will be impaired.

In an effort to solve the problems present in the rack and cloth hydraulic processing operation, studies were conducted to adapt one of the new machines now available to the coconut milk extraction process on the market. A screw press designed primarily for the extraction of grape juice was used in this work. The results of the study are presented herewith.

\section{MATERIALS AND METHODS}

The coconuts used in the experiments were purchased at the fresh-produce market. They were husked and the nuts sorted before processing. Nuts were discarded which were soft in the eye at the embryo end, cracked or immature. Selected nuts were heated to $307^{\circ} \mathrm{F}$ (60 lbs steam pressure) for $8 \mathrm{~min}$ in a high-pressure vessel (1). The retort was equipped for a fast coming-up and an instant release of pressure during the operation. Immediately after the heat treatment the coconuts were broken in a coconut breaking machine (2). The broken nuts were carried by a conveyor to a sorting table where the pulp was separated and fed into a washing reel. The clean

1 Manuscript submitted to Editorial Board December 10, 1973.

2 Food Scientist and Research Assistants, respectively, Food Technology Laboratory, Agricultural Experiment Station, Mayagüez Campus, University of Puerto Rico, Rio Piedras, P.R. 
pulp was weighed and ground in a hammer mill equipped with a No. 4 screen (10 1/4-inch perforations/in $\left.{ }^{2}\right)$. One part by weight of water was added to every two parts of pulp in the comminuting mill.

The comminuted pulp was weighed before feeding into the screw-press. An initial amount of $30 \mathrm{lbs}$ of comminuted pulp was fed into the press to fill the machine and leave it in actual pressing condition. One hundred lbs of pulp were used per run. Material was added to the press in such a way as to just fill the inlet space of the machine cylinder. Bridging was avoided by making sure not to over fill this space. Time was recorded during the feeding operation, and an additional $2 \mathrm{~min}$ were allowed to empty the press. This timing procedure was followed for all the experiments in order to duplicate pressing conditions. A record of the weight of the mash, the time needed to feed the machine, the weight of the coconut milk and that of the screw-press cake (pressed residue) was kept for each run. Samples of the coconut milk and press cake were taken and weighed for chemical analyses.

Fourteen lbs of solid residue from the screw press were squeezed in the hydraulic press to evaluate the continuous press operation. This evaluation was carried out by pressing the solid residue under a pressure of $185 \mathrm{lbs} / \mathrm{in}^{2}$ and holding it for $1 \mathrm{~min}$. The weights of the coconut milk and of the solid residue left were recorded. The practical efficiency of the operation was calculated from the results obtained. These pressing conditions were used for the evaluation, as they are the optimum ones for maximum extraction of coconut milk.

The screw press used was a Rietz Horizontal Continuous S-Press Model No. $6^{3}$ equipped with a variable speed drive at the main screw shaft to control the capacity of the press and with a 0.023 -in perforation screen. In this machine the speed of the creeping cone (discharge end valve of the cylinder) was $3 \mathrm{r} / \mathrm{min}$. The pressure needed to operate the creeping cone was provided by a high pressure nitrogen tank connected to the hydraulic piston of the accessory. Working pressure on the discharge end valve was regulated through a pressure regulator on the machine and another placed in the tank. With the use of the nitrogen tank no fluctuations were observed in the system during the operation. This made it possible to make precise adjustments of pressure ranging from 60 to $200 \mathrm{lbf} / \mathrm{in}^{2}$.

As all the previous experiences in the extraction of coconut milk suggested pressures close to $180 \mathrm{lbf} / \mathrm{in}^{2}(1)$, the work was started with variations ranging from 160 to $200 \mathrm{lbf} / \mathrm{in}^{2}$. The results of the experiments revealed no

8 Trade names are used in this publication for the sole purpose of providing specific information. Mention of a trade name does not constitute a guarantee or warranty of the equipment by the Agricultural Experiment Station of the University of Puerto Rico or an endorsement over other equipment not mentioned. 
definite trends in capacity, efficiency and yield of operation at these high pressures. On the other hand, detrimental effects were observed with these working pressures in the machine, such as an excessive leakage through the retainer in the creeping cone. Besides, the coconut milk produced contained an excess of coconut pulp particles. For these reasons high pressures were discarded.

An initial experimental survey of the effect of pressure in the extraction of coconut milk, starting with a level as low as $20 \mathrm{lbf} / \mathrm{in}^{2}$, led to the establishment of pressure limits for the study. Because in this preliminary study pressures under $50 \mathrm{lbf} / \mathrm{in}^{2}$ resulted in cake with a high coconut milk content, it was decided to set the pressures between 60 and $180 \mathrm{lbf} / \mathrm{in}^{2}$ and the speed from 8.5 to $17.5 \mathrm{r} / \mathrm{min}$.

The evaluation of the performance of the continuous screw press will be presented by using six indices: capacity, efficiency, and extraction yield of the machine, and percent of coconut milk, water, and fat (dry basis) remaining in the press cake.

\section{RESULTS AND DISCUSSION}

The capacity of the screw press is shown in the curves obtained by plotting the results of the experiments performed (fig. 1). With speeds of 8.5 and $12.5 \mathrm{r} / \mathrm{min}$, the pressure does not-seem to influence, in a fixed pattern, the amount of coconut pressed per hour. At these two speeds, the capacity remains almost constant, with irregular fluctuations that can be explained by the inconsistency of the operator in feeding the machine. The screw press has an increase in capacity of about 30 percent when the speed is raised from 8.5 to $12.5 \mathrm{r} / \mathrm{min}$. The results show that at a speed of $17.5 \mathrm{r} / \mathrm{min}$ a reducing effect occurs in the capacity of the machine as the pressure is increased from 60 to $180 \mathrm{lbf} / \mathrm{in}^{2}$. The pressure at the discharge valve is great enough to reduce the release of solid material. This also is corroborated by the coconut milk obtained at higher pressures which contains more pulp particles forced through the screen by the excessive pressure inside.

Raising the speed of the press from 8.5 to $17.5 \mathrm{r} / \mathrm{min}$ at $100 \mathrm{lbf} / \mathrm{in}^{2}$, there is an increase in capacity of 125 percent, reaching a level of $3,000 \mathrm{lbs}$ of comminuted pulp/hr.

Another index to evaluate the performance of the screw press is its efficiency as compared to the batch hydraulic press, taking the latter as 100 percent efficient.

Percent efficiency $=$ weight of coconut milk from screw press/weight of coconut milk from screw press + weight of coconut milk obtained from residue of screw press when placed in hydraulic press $\times 100$ 


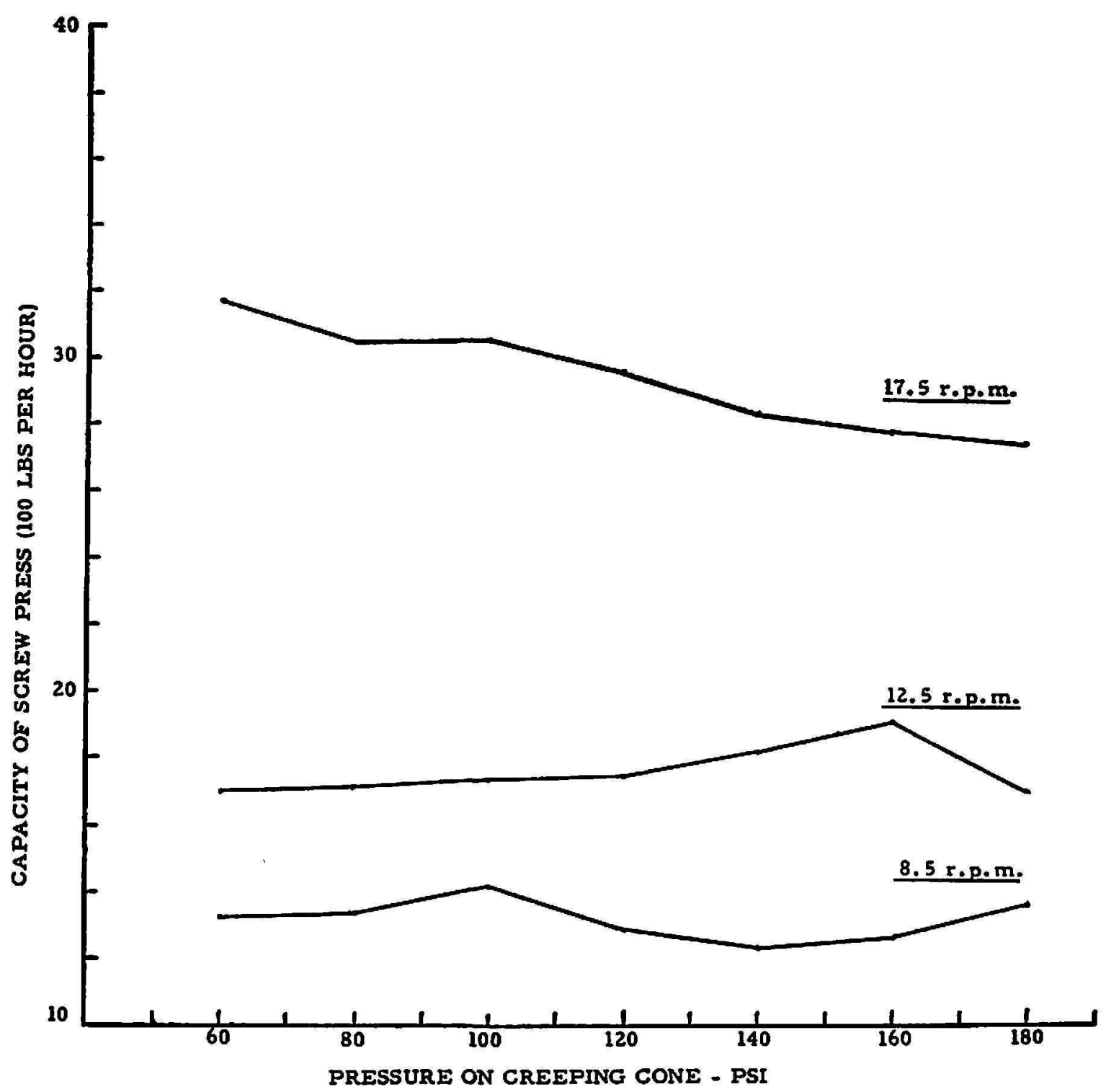

Fra. 1.-Amount of comminuted coconut pulp pressed at seven different pressures on the creeping cone and three different speeds.

The curves presented in figure 2 (top) were obtained by plotting the figures calculated from the results. Irrespective of the pressure, the data show that the highest efficiency is obtained with a speed of $8.5 \mathrm{r} / \mathrm{min}$ followed by a speed of 12.5 and finally $17.5 \mathrm{r} / \mathrm{min}$. As the pressure is increased, the efficiency seems to reach a common level, disregarding the difference in $\mathrm{r} / \mathrm{min}$ of the cone. It is important to notice that the difference in efficiency is only 2.5 percent at most $\left(60 \mathrm{lbf} / \mathrm{in}^{2}\right)$ going down to 0.6 percent at 180 $\mathrm{lbf} / \mathrm{in}^{2}$.

The percent yield index, the amount expressed in pounds of coconut milk extracted from $100 \mathrm{lbs}$ of comminuted pulp (fig. 2, middle curves), shows that the performance of the screw press varies inversely with the increase in 


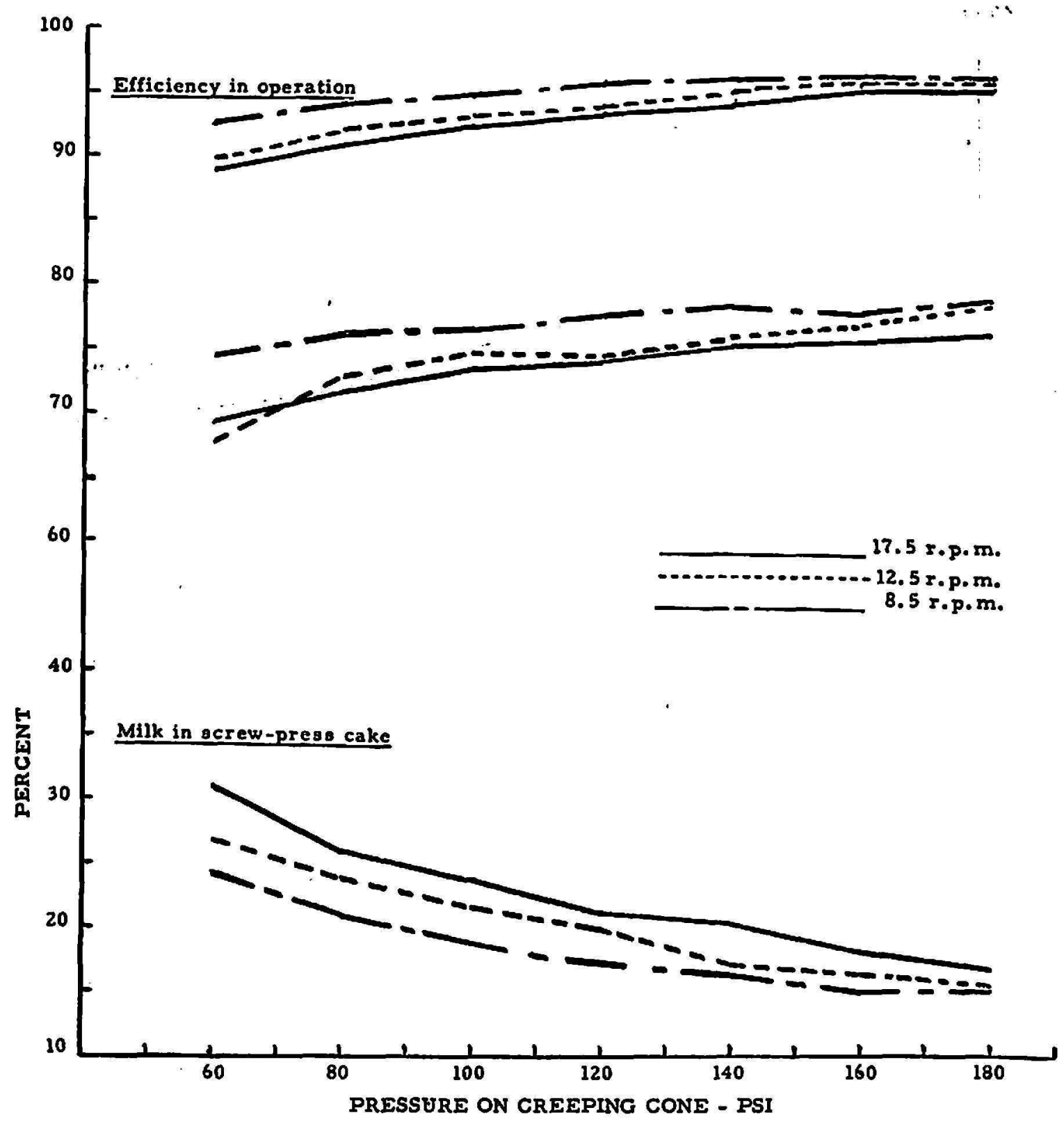

Fra. 2.-Performance of the screw-press in extracting coconut milk at seven differ- ' ent pressures on the creeping cone and three different speeds.

speed. The yield is highest at the lower speed of $8.5 \mathrm{r} / \mathrm{min}$, followed by 12.5 $\mathrm{r} / \mathrm{min}$ and $17.5 \mathrm{r} / \mathrm{min}$. The results of the experiments show a yield difference of about 6 percent for $60 \mathrm{lbf} / \mathrm{in}^{2}$, going down to 2.5 percent at 180 $\mathrm{lbf} / \mathrm{in}^{2}$.

The results of the coconut milk extraction in the screw-press cake (fig. 2, bottom curves) show that the most complete extraction is obtained at 8.5 $\mathrm{r} / \mathrm{min}$, followed by 12.5 and 17.5 . These results agree with those given by the percent yield curve.

The results of the water and fat analysis in the screw-press cake are presented in figure 3. Water content in press-cake from extractions at $\mathbf{8 . 5}$ 
and $12.5 \mathrm{r} / \mathrm{min}$ are within 1 percent, but the results for $17.5 \mathrm{r} / \mathrm{min}$ differ from the latter by 3.5 to 4.0 percent. Fat analyses of the screw-press cake show a definite difference in fat content between the three pressing conditions, but these differences are not related to speed.

In a practical evaluation using the calculated indices obtained from the results of the study carried out, it was concluded that the best conditions to operate the screw press for the extraction of coconut milk are a speed of $17.5 \mathrm{r} / \mathrm{min}$ and a pressure of $100 \mathrm{lbf} / \mathrm{in}^{2}$ in the creeping cone (solids release valve). The efficiency index shows that the performance of the screw press is 90 to 95 percent as efficient as that of the hydraulic press but it reduces

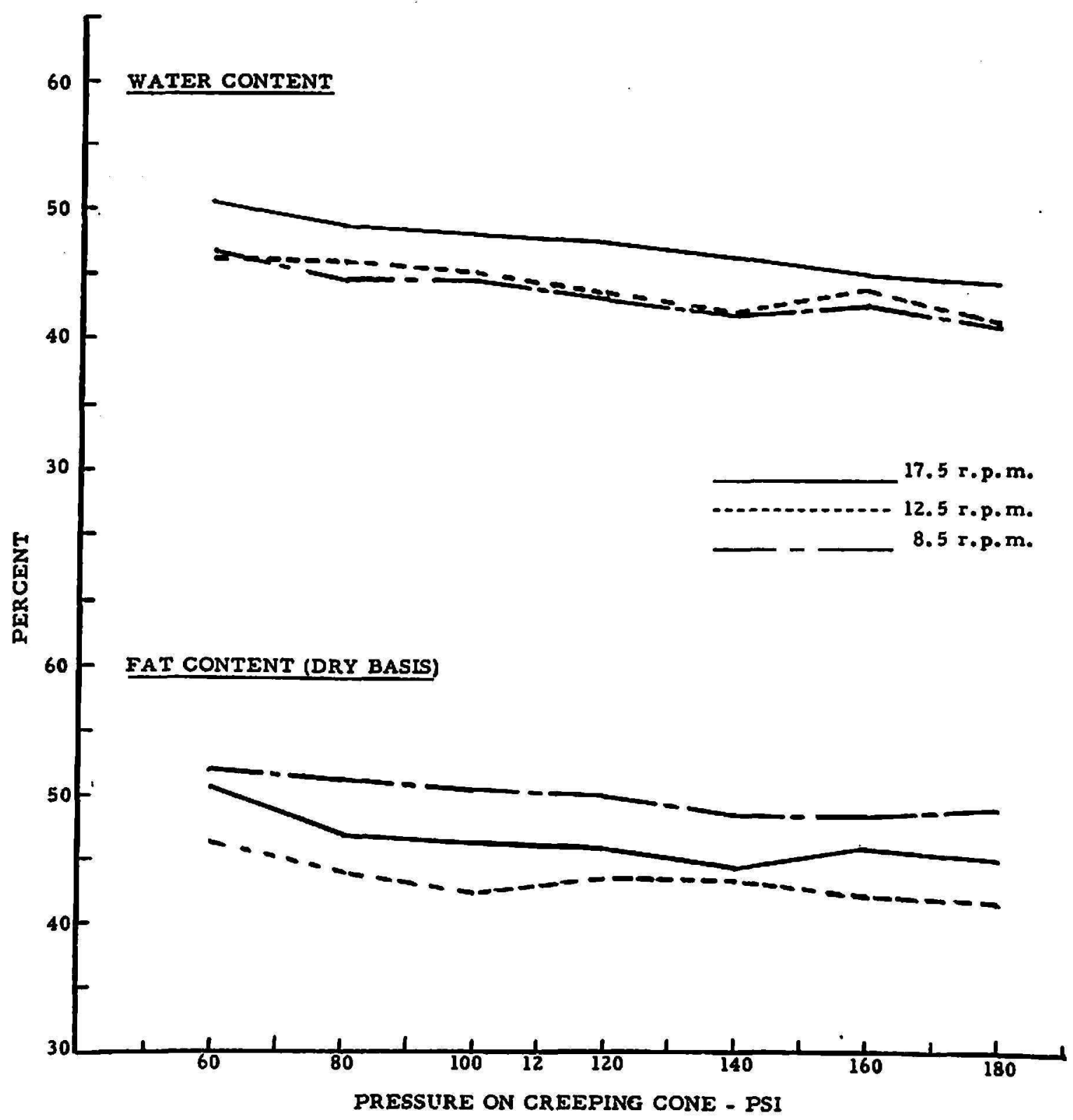

FIG. 3.-Chemical analysis of screw-press cake obtained from experiments at seven different pressures and three different speeds. 
operating costs and permits continuity in the coconut milk extraction. The yield values show that the difference between coconut milk extraction at different speeds ( 5 to $7 \%$ ) is not comparable to the difference in capacity at the speeds used (125 percent increase). Chemical analyses of the coconut milk and press cake reveal no trend in the fat content of either product with respect to the treatments given.

\section{SUMMARY}

Studies were conducted on the extraction of coconut milk using a continuous screw press. Speeds of $8.5,12.5$, and $17.5 \mathrm{r} / \mathrm{min}$ were used on the pressing screw. Pressures of 60, 80, 100, 120, 140, 160 and $180 \mathrm{lbf} / \mathrm{in}^{2}$ were used on the creeping cone, which in this machine serves as a solids releasing valve. A hydraulic press was used to evaluate the screw-press cake by completely removing the remaining coconut milk from the pressed solid material under a direct pressure of 185 p.s.i. $/ \mathrm{m}^{2}$ for 1 minute.

The results of the experiments indicate a gradual increase in efficiency in the coconut milk extraction process as the pressure is augmented from 60 to $180 \mathrm{lbf} / \mathrm{in}^{2}$, with a more pronounced effect within the range of 60 to 100 $\mathrm{lbf} / \mathrm{in}^{2}$. The increase in efficiency ranged from 3.5 percent at $8.5 \mathrm{r} / \mathrm{min}$ to 6.5 percent at $7.5 \mathrm{r} / \mathrm{min}$.

Capacity in the performance of the press is the characteristic most affected by changes in speed of the pressing screw. The capacity at a speed of $17.5 \mathrm{r} / \mathrm{min}$ dropped from 3,160 to $2,720 \mathrm{lbs} / \mathrm{hr}$. With a speed of $12.5 \mathrm{r} / \mathrm{min}$ the capacity fluctuated between 1,800 and $1,700 \mathrm{lbs} / \mathrm{hr}$, and at $8.5 \mathrm{r} / \mathrm{min}$ it was about $1,300 \mathrm{lbs} / \mathrm{hr}$.

The recommended set of conditions to extract coconut milk using this type of continuous screw-press are a speed of $17.5 \mathrm{r} / \mathrm{min}$ and a pressure of $100 \mathrm{lbs}$ on the creeping cone, when working with comminute material from a hammer mill with a No. 4 screen $\left(101 / 4\right.$-in perforations/in $\left.{ }^{2}\right)$.

\section{RESUMEN}

Se estudió el procedimiento para extraer leche de coco usando una prensa de tornillo de operación continua, a velocidades de 8.5, 12.5 y 17.5 r.p.m. en el tornillo alimentador y presiones de $60,80,100,120,140,160$ y 180 p.s.i. en el cono-válvula a la salida de la prensa. En la evaluación de la operación de la prensa de tornillo se usó una prensa hidráulica, calibrada para trabajar a una presión de $185 \mathrm{p} .8 . i . / \mathrm{m}^{2}$ for 1 minute.

El residuo sólido de la prensa de tornillo se sometió a la acción de la prensa hidráulica para extraer la leche de coco residual. Los resultados de los experimentos indican un aumento gradual en la eficiencia del proceso de extracción de leche de coco, según se aumenta la presión en el cono-válvula de 60 a $180 \mathrm{lbs} . / \mathrm{pulg} .{ }^{2}$, notándose, sin embargo, un cambio más pronunciado entre 60 y $100 \mathrm{lbs}$. de presión. El aumento en la eficiencia a una velocidad de 17.5 r.p.m. fluctúa entre 3.5 y 6.5 por ciento.

En el funcionamiento de la prensa de tornillo, es la capacidad la característica que más se afecta con los cambios en la velocidad del tornillo alimentador. Esta varía de 
2,720 a 3,160 lbs. por hora a una velocidad de 17.5 r.p.m.; de 1,700 a 1,800 lbs. a 12.5 r.p.m.; y fluctúa alrededor de 1,800 lbs. a una velocidad de 8.5 r.p.m.

Como resultado del estudio efectuado se recomiendan las siguientes condiciones para el funcionamiento de la prensa de tornillo en la extracción de leche de coco: una velocidad de 17.5 r.p.m. en el tornillo sinfín; 100 libras de presión por pulgada cuadrada en el cono-válvula; y la molienda de la pulpa de coco en un molino de martillos equipado con un cedazo Núm. 4 (10 perforaciones de 0.25 pulgada/pulg. ${ }^{2}$ de diámetro de superficie).

\section{LITERATURE CITED}

1. Cancel, L. E., Method of shelling coconuts, U.S. Patent 3,225,804, 1965.

2. - Coconut breaking machine, U.S. Patent 3,695,834, 1969.

3. - Coconut food products and bases, Chapter 9, Coconuts: Production-Processing-Products, edited by J. G. Woodroof, Avi Publishing Co., Westport, Conn., 162-88, 1970.

4. Hagenmaier, R., Cater, C. M., and Mattil, K. F., Critical unit operations of the aqueous processing of fresh coconuts, J. Am. Oil Chem. Soc. 49 (3) : 178-81, 1965.

5. Lava, V. G., Oil recovery, U.S. Patent 2,101,371, 1937.

6. Raxas, P. G., Process of recovering oils from oleoginous meats of nuts, beans and seeds, U.S. Patent 3,083,365, 1963. 